EKSAKTA Vol. 19 No. 1

30 April 2018

http://eksakta.ppj.unp.ac.id

E-ISSN : 2549-7464

P-ISSN : 1411-3724

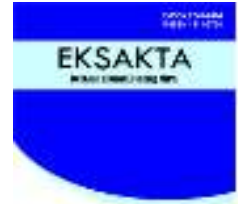

$-\cdots=E$

\title{
PERTUMBUHAN STEK HORIZONTAL BATANG JARAK PAGAR (Jatropha curcas L.) YANG DIINTRODUKSI DENGAN PSEUDOMONAD FLUORESEN
}

\author{
Linda Advinda, Mades Fifendy, Azwir Anhar, Irma Leilani, Adek Liza Sahara
}

Jurusan Biologi, FMIPA, Universitas Negeri Padang, Padang

e-mail : linda_advinda@yahoo.com

DOI : 10.24036/eksakta/vol19-iss01/129

\begin{abstract}
Jatropha curcas $L$. is one of the plants that can be developed as raw material of biodiesel. One of the efforts to increase the production of J. curcas is the propagation of stem cuttings horizontally. Efforts to stimulate root growth can be accomplished by adding Plant Growth Regulators (PGRs). PGRs can be obtained naturally or synthetically. Indole acetic acid (IAA) is one of PGRs, which is not only produced by plants but can also be produced by rhizobacteria. One such rhizobacteria is fluorescent pseudomonad. The objectives of the study were to know the response of growth of horizontal stem cuttings after being introduced with fluorescent pseudomonad. This research is an experimental research. Complete Randomized Design with 6 treatments and 4 replications. The treatments were soaking of J. curcas stem cuttings with fluorescent pseudomonad isolate suspension PfPj3 suspension concentration of $0 \%$ (without suspension), 5\%, 10\%, 15\%, $20 \%$, and 25\%. Observation of the research is the beginning of the shoots, the number of shoots, and the length of the J. curcas stem shoot. The data obtained were analyzed using Anova and DNMRT significant level of 5\%. The results showed that horizontal stem cuttings of J. curcas with fluorescent pseudomonad suspension influenced early shoot, shoot number, and shoot length. A $10 \%$ fluorescent pseudomonad concentration can cause shoots to appear early, while a concentration of $20 \%$ causes the largest number of shoots.
\end{abstract}

Keywords: stem cutting, IAA, fluorescent pseudomonad

\section{PENDAHULUAN}

Jarak pagar (Jatropha curcas L.) merupakan jenis tanaman semak atau pohon yang masuk ke dalam famili Euphorbiaceae. Pada saat ini jarak pagar merupakan salah satu komoditas pertanian yang dapat dijadikan sebagai bahan bakar nabati. Minyak jarak pagar dapat digunakan sebagai bahan baku utama pembuatan biodiesel. Menurut
Purwanto (2008), guna memenuhi kebutuhan bibit yang tepat waktu sesuai kebutuhan di lapangan dengan kualitas baik, perlu diupayakan bibit jarak pagar berupa stek. Meskipun tanaman ini dapat diperbanyak secara vegetatif (stek) maupun generatif (biji).

Berbagai metode untuk stek tanaman sudah banyak dikenal. Untuk perbanyakan tanaman, ternyata stek batang lebih efisien dibandingkan dengan 
cara lainnya. Pertumbuhan tanaman yang berasal dari stek batangpun lebih cepat. Disamping itu, stek batang mampu menyediakan bibit dalam jumlah yang banyak, serta dapat dilakukan sepanjang waktu selama tersedianya pohon sumber.

Perbanyakan tanaman jarak pagar dengan stek batang secara vertikal sudah umum digunakan, namun dari stek tersebut hanya menghasilkan satu tanaman baru. Untuk memperoleh bibit dalam jumlah besar akan membutuhkan induk tanaman yang banyak pula. Hal ini sangat tidak efektif sehingga diperlukan satu metode penanam stek yang baru, yakni penanaman stek secara horizontal. Penanaman stek batang yang ditanam secara horizontal diharapkan mampu menghasilkan bibit baru yang lebih banyak dari setiap nodus, jika lingkungannya memungkinkan baik internal maupun eksternal (Pamungkas dkk, 2009).

Penanaman stek batang jarak pagar secara horizontal memerlukan waktu yang cukup lama untuk terbentuknya akar. Usaha untuk merangsang pertumbuhan akar bisa dilakukan dengan menambahkan Zat Pengatur Tumbuh (ZPT). ZPT dapat diperoleh secara alami maupun sintetik. Indole acetic acid (IAA) merupakan salah satu ZPT, yang tidak hanya dihasilkan oleh tumbuhan tetapi dapat juga dihasilkan oleh rizobakteri. Doktycz, et al., (2014) menyatakan rizobakteri adalah bakteri yang mengkolonisasi perakaran tanaman dan biasanya hidup sebagai endosimbiosis.

$$
\text { Rizobakteri dari genus }
$$

Pseudomonas, Azotobacter, Bacillus, Azospirillum, Bradyrhizobium dan Rhizobium diidentifikasi sebagai Plant Growth Promoting Rhizobacteria
(PGPR). PGPR paling kurang harus memiliki tiga karakter untuk dapat meningkatkan pertumbuhan tanaman, yaitu: kemampuan mengkolonisasi akar, fitostimulator, dan agen biokontrol terhadap patogen tanaman (Bloemberg and Lugtenberg, 2001). Menurut van Loon (2007), rizobakteri dapat mengendalikan penyakit tanaman melalui beberapa cara, seperti: produksi senyawa antimikroba, persaingan pemanfaatan unsur Fe melalui produksi siderofor, induksi sistem ketahanan, inaktivasi faktor perkecambahan patogen, dan persaingan ruang atau nutrisi.

Hasil penelitian Wahyudi dkk (2011) dilaporkan 14 isolat pseudomonad fluoresen yang berhasil diisolasi adalah nonpatogen, menghasilkan IAA, dan dapat meningkatkan panjang akar, panjang tunas, serta jumlah akar lateral tanaman kedelai. Anhar dkk (2011) menyatakan isolat pseudomonad fluoresen Cas3 terbaik dalam meningkatkan jumlah anakan dan tinggi tanaman padi. Advinda (2010) melaporkan isolat pseudomonad fluoresen Cas3, PfPj2, dan PfPj3 terbaik dalam mengendalikan penyakit Blood Disease Bacteria (BDB) tanaman pisang. Selanjutnya Pamungkas dkk (2009) melaporkan pemberian rizobakteri Bacillus (konsentrasi 25\%) menghasilkan jumlah daun dan berat akar terbaik dari stek horizontal jarak pagar. Sedangkan penelitian ini menginformasikan tentang pertumbuhan stek horizontal batang jarak pagar (Jatropha curcas L.) yang diintroduksi dengan rizobakteri pseudomonad fluoresen.

\section{METODE PENELITIAN}

\begin{tabular}{ccc}
\multicolumn{2}{c}{ Penelitian ini } & merupakan \\
penelitian eksperimen. & Rancangan
\end{tabular}


penelitian Acak Kelompok dengan 6 perlakuan dan 4 ulangan. Perlakuan yang diberikan adalah perendaman stek batang jarak pagar dengan suspensi pseudomonad fluoresen isolat $\mathrm{PfPj} 3$ konsentrasi suspensi 0\% (tanpa suspensi), $5 \%, 10 \%, 15 \%, 20 \%$, dan $25 \%$. Pengamatan penelitian adalah awal muncul tunas, jumlah tunas, dan panjang tunas stek batang jarak pagar. Data yang diperoleh dianalisis menggunakan Anova dan uji lanjut DNMRT pada taraf nyata $5 \%$.

\section{Peremajaan dan perbanyakan pseudomonad fluoresen}

Isolat diremajakan dalam cawan petri pada medium King's B padat dengan metode gores. Setelah 2x24 jam inkubasi, dilakukan perbanyakan inokulum menggunakan $50 \mathrm{~mL}$ medium King's B cair dan di shaker selama 24 jam. Hasil akhir merupakan konsentrasi $100 \%$ dari suspensi pseudomonad fluoresen.

\section{Persiapan stek batang jarak pagar}

Batang jarak pagar yang digunakan diperoleh dari daerah Gaduik Padang. Batang yang diambil dengan ukuran diameter 1,5 sampai $2,5 \mathrm{~cm}$. Jumlah mata tunas stek yang digunakan adalah 10 mata tunas. Jumlah stek yang digunakan sebanyak 24 buah. Setelah dilakukan pemotongan batang jarak pagar, selanjutnya stek tersebut disimpan di tempat yang teduh selama beberapa hari.

\section{Persiapan media tanam}

Media tanam yang digunakan terdiri dari campuran tanah dengan kompos (perbandingan 1:5). Selanjutnya sebanyak $3 \mathrm{~kg}$ media tanam tersebut dimasukkan ke dalam polybag berukuran $45 \mathrm{x} 40 \mathrm{~cm}$.

\section{Perendaman stek batang jarak pagar dengan suspensi pseudomonad fluoresen}

Dilakukan perendaman stek batang jarak pagar dalam suspensi pseudomonad flouresen konsentrasi 0\% (A), 5\% (B), 10\% (C), 15\% (D), 20\% (E), dan $25 \%$ (F) selama 2 jam.

\section{Penanaman stek batang jarak pagar}

Stek batang jarak pagar yang telah direndam suspensi pseudomonad fluoresen ditanam dalam media tanam yang telah disiapkan dalam posisi horizontal. Masing-masing polybag terdapat satu potong stek batang jarak pagar. Pemeliharaan stek batang dilakukan dengan menyiramnya setiap hari dan penyiangan dari gulma yang ada dalam polybag.

\section{Pengamatan}

a. Awal muncul tunas

Awal muncul tunas diamati dari awal stek ditanam hingga munculnya mata tunas pertama kali, yang menandakan bahwa stek sudah bertunas.

b. Jumlah tunas

Menghitung jumlah tunas setiap minggu dimulai dari tunas pertama muncul. Pengukuran dilakukan sekali dalam satu minggu, hingga tanaman berumur 5 minggu setelah tanam (MST).

c. Panjang tunas

Pengamatan panjang tunas dilakukan setiap minggu semenjak tunas pertama kali muncul. Mengukur panjang tunas mulai dari pangkal tempat tumbuh tunas sampai ujung daun paling tinggi, dengan cara meluruskan daun ke atas. Pengukuran dilakukan sekali dalam satu minggu, hingga tanaman berumur 5 minggu setelah tanam (MST).

HASIL DAN PEMBAHASAN

Awal muncul tunas 
Hasil pengamatan perendaman stek horizontal batang jarak pagar terhadap kecepatan tumbuhnya tunas menunjukkan suspensi pseudomonad fluoresen mampu mempercepat proses pertunasan (Tabel 1).

Tabel 1. Awal muncul tunas stek horizontal batang jarak pagar

\begin{tabular}{|c|c|c|c|c|c|c|c|}
\hline \multirow{2}{*}{ Perlakuan } & \multicolumn{7}{|c|}{ Hari ke } \\
\cline { 2 - 8 } & 1 & 2 & 3 & 4 & 5 & 6 & 7 \\
\hline A $(0 \%)$ & - & - & - & - & v & - & - \\
\hline B $(5 \%)$ & - & - & - & - & - & v & - \\
\hline C $(10 \%)$ & - & - & v & - & - & v & - \\
\hline D $(15 \%)$ & - & - & - & - & - & v & - \\
\hline E $(20 \%)$ & - & - & - & - & v & - & - \\
\hline F $(25 \%)$ & - & - & - & - & - & v & - \\
\hline
\end{tabular}

keterangan: $\mathrm{v}=$ awal muncul tunas

Perendaman stek horizontal batang jarak pagar dengan suspensi pseudomonad fluoresen, mampu mempercepat waktu munculnya tunas. Stek jarak pagar yang direndam dengan pseudomonad fluoresen konsentrasi $10 \%$, memperlihatkan munculnya tunas lebih awal dari pada perlakuan kontrol maupun konsentrasi pseudomonad fluoresen lainnya. Menurut Hidayanto dkk (2003), penggunaan ZPT (natrium-nitrofenol) eksogen dapat memacu aktivitas auksin endogen, sehingga memacu pembentukan tunas lebih awal. Natrium-nitrofenol bekerja secara biokimiawi, meresap lewat akar, daun dan kuncup, sehingga mempengaruhi proses aliran massa ke dalam sel dan memberikan kekuatan vital untuk menggiatkan pertumbuhan. Pada penelitian ini, tunas adalah organ pertama yang muncul dari stek horizontal jarak pagar, sehingga pseudomonad fluoresen dapat memacu pertumbuhan tunas tersebut.

Pseudomonad fluoresen konsentrasi 5\%, 15\%, 20\%, dan $25 \%$ belum dapat menunjukkan respon pertunasan lebih awal, karena konsentrasi tersebut belum cocok dan seimbang dalam memacu pertunasan. Menurut Irwanto (2003) pertumbuhan dan perkembang tunas dikontrol oleh adanya keseimbangan hormon dalam tanaman. Ördög dan Zoltán (2011) menambahkan, 
interaksi hormon auksin dan sitokinin menjadi penentu terbentuknya tunas. Perbandingan yang tepat antara kedua hormon tersebut dapat meningkatkan pembelahan dan diferensiasi sel.

\section{Jumlah Tunas}

Jumlah tunas stek batang jarak pagar dihitung mulai minggu pertama setelah tanam (1 MST) sampai 5 MST. Pada minggu pertama setelah tanam (1 MST) terlihat jumlah tunas pada perlakuan kontrol A (0\%) mempunyai jumlah tunas paling banyak, diikuti oleh perlakuan suspensi pseudomonad fluoresen $\mathrm{E}$ (20\%) (Gambar 1.).

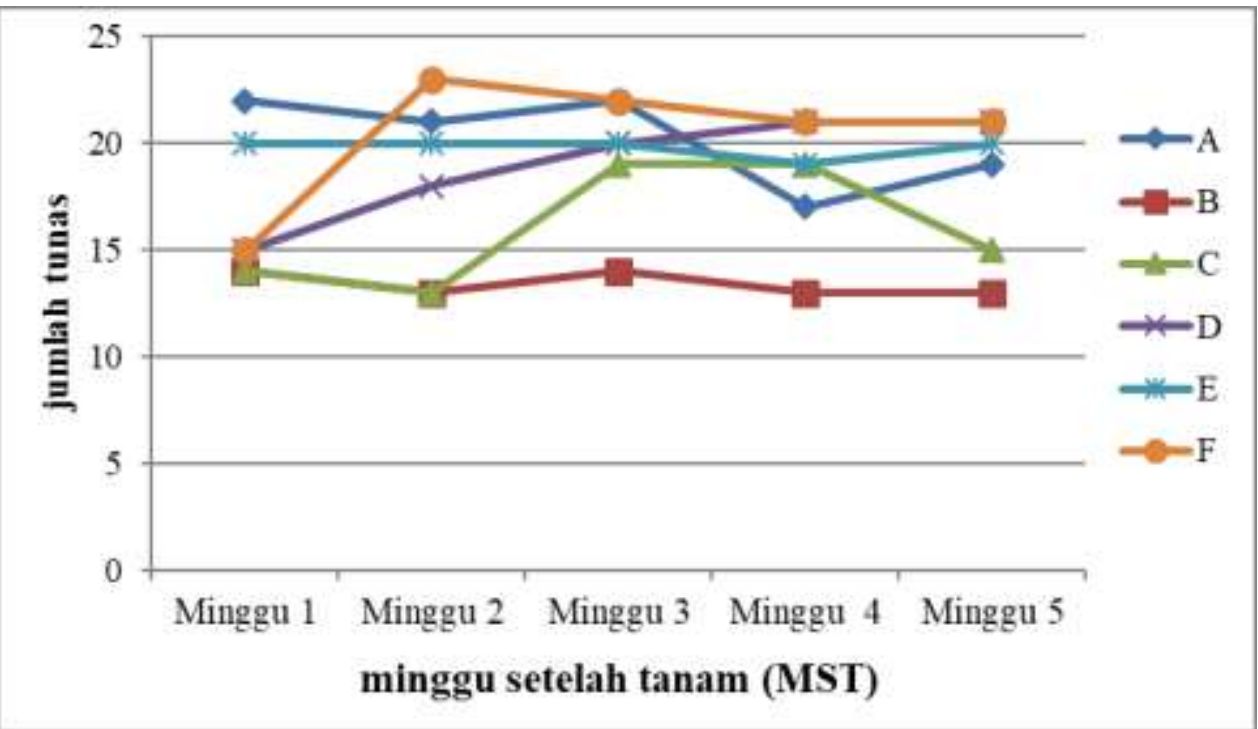

Gambar 1. Jumlah tunas stek jarak pagar yang direndam dengan pseudomonad fluorensen konsentrasi A (0\%), B (5\%), C (15\%), D (20\%), dan E (25\%)

Pada 4 MST terjadi pengurangan jumlah tunas cukup banyak pada perlakuan A (0\%), walaupun meningkat kembali pada 5 MST. Sedangkan jumlah tunas yang cukup banyak dan stabil hingga akhir pengamatan (5 MST) terdapat pada perlakuan perendaman stek batang jarak pagar dengan suspensi pseudomonad fluoresen E (20\%). Jika dihubungkan dengan panjang tunas stek batang jarak pagar yang direndam suspensi pseudomonad fluoresen (Gambar 2.), terlihat pada 5 MST panjang tunas terendah pada perlakuan E (20\%). Dalam hal ini terlihat bahwa perlakuan suspensi pseudomonad fluoresen E (20\%) mempunyai jumlah tunas stek batang jarak pagar terbanyak, meskipun tunas tersebut lebih kecil dari perlakuan lainnya.

Sama halnya dengan auksin, sitokinin juga sebagai pengatur utama untuk berbagai aspek pertumbuhan dan perkembangan tumbuhan. Homeostasis sitokinin merupakan pengaturan secara spasial dan temporal untuk keseimbangan antara sintesis dan katabolisme. Aktivitas sitokinin mendorong pembelahan sel 
untuk inisiasi pembentukkan tunas $(\mathrm{Su}$ et al., 2011). Wang dan Irving (2011) menyatakan, disamping mendorong pembelahan sel, sitokinin juga dapat mendorong diferensiasi jaringan tertentu dalam pembentukan tunas pucuk dan pertumbuhan akar. Keberadaan hormon auksin dan sitokinin yang seimbang dapat mengontrol pertumbuhan dan perkembangan tumbuhan. Hormon secara mandiri tidak memberi pengaruh yang optimal untuk pertumbuhan dan perkembangan tumbuhan.

\section{Panjang Tunas}

Panjang tunas dari stek batang jarak pagar dihitung mulai minggu pertama setelah tanam (1 MST) sampai 5 MST. Pengamatan 5 MST terlihat panjang tunas stek horizontal batang jarak terpanjang terdapat pada perlakuan perendaman dengan suspensi pseudomonad fluoresen C $(10 \%)$ yaitu $49,95 \mathrm{~cm}$ dan yang terkecil pada kontrol A (0\%) yaitu 20,91 cm (Gambar 2.)

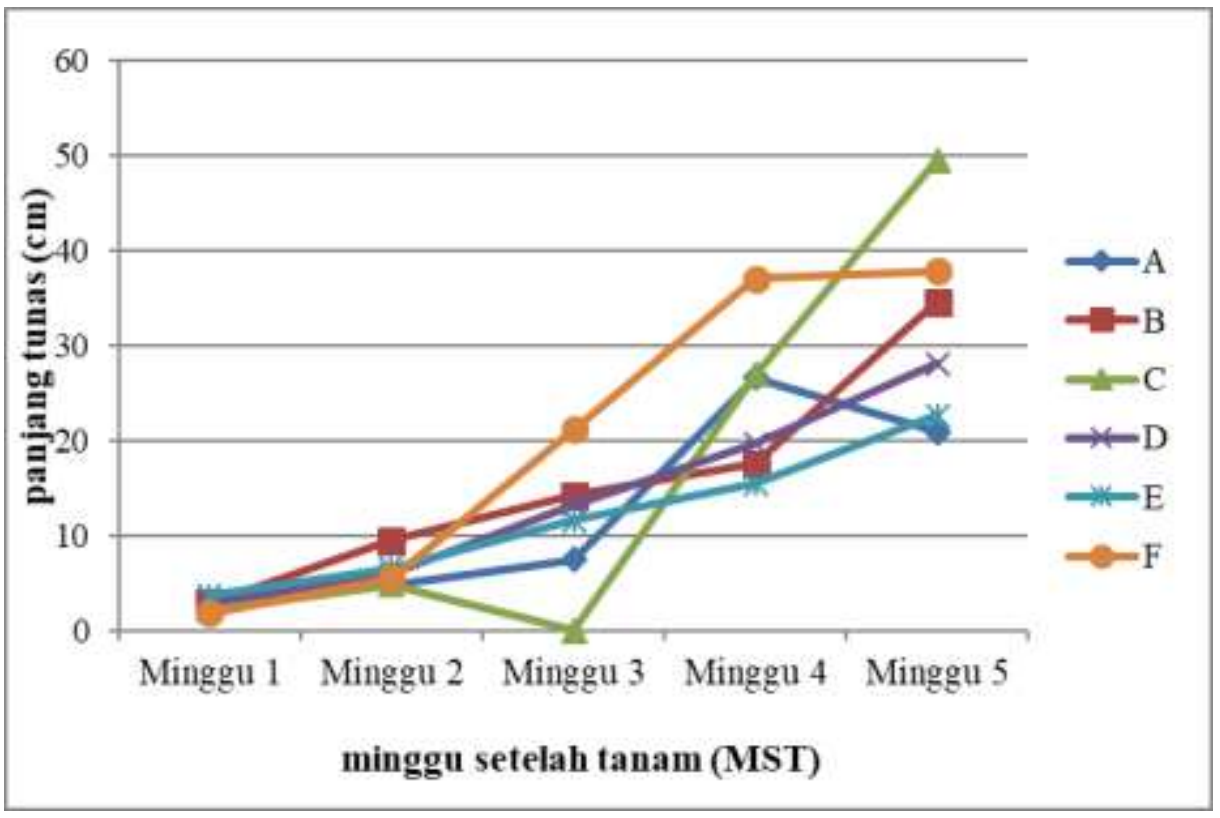

Gambar 2. Panjang tunas stek jarak pagar yang direndam dengan pseudomonad fluorensen konsentrasi A (0\%), B (5\%), C (15\%), D (20\%), dan E (25\%)

Hasil analisis sidik ragam terhadap panjang tunas stek horizontal batang jarak pagar pada 5 MST memperlihatkan $\mathrm{F}$ hitung lebih besar dari F tabel. Setelah dilakukan uji lanjut DMRT 5\% terlihat perlakuan suspensi pseudomonad fluoresen B (5\%), C (10\%), D (15\%), dan $\mathrm{F}(25 \%)$ tidak berbeda nyata, namun berbeda nyata dengan perlakuan A $(0 \%)$ dan E (20\%). Perbedaan pertambahan panjang tunas juga dipengaruhi oleh perbandingan hormon auksin dan sitokinin.

Peran hormon auksin dan sitokinin dalam sel tambuhan berbeda. Sitokinin dalam sel tumbuhan akan merangsang pembelahan sel melalui peningkatan laju sintesis protein. Sedangkan auksin akan memacu pemanjangan sel-sel, sehingga terjadi 
pemanjangan batang (Ördög and Zoltán, 2011). Menurut Advinda (2018) auksin banyak dibentuk pada jaringan meristematik di ujung-ujung tanaman seperti tunas, ujung akar, kuncup bunga, pucuk daun dan lain-lain. Auksin meningkatkan permeabilitas dinding sel, sehingga pengambilan ion-ion ke dalam sel pun meningkat. Sel-sel tersebut menjadi panjang-panjang dan mengandung banyak air. Pengambilan air yang bersamaan dengan penambahan plastisitas dinding sel, memungkinkan sel untuk memanjang.

\section{SIMPULAN DAN SARAN}

\section{Simpulan}

Dari hasil penelitian dapat disimpulkan bahwa:

1. Perendaman stek horizontal batang jarak pagar dengan suspensi pseudomonad fluoresen mempengaruhi awal muncul tunas, jumlah tunas, dan panjang tunas.

2. Munculnya tunas lebih awal didapatkan pada stek batang jarak pagar yang direndam dengan suspensi pseudomonad fluoresen (konsentrasi $10 \%)$.

3. Jumlah tunas terbanyak dihasilkan setelah stek batang jarak pagar direndam dengan suspensi pseudomonad fluoresen (konsentrasi $20 \%$ ), namun panjang tunasnya lebih kecil.

\section{Saran}

Saran dari penelitian ini adalah introduksi pseudomonad fluoresen terhadap bahan perbanyakan vegetatif tanaman lain nya.

\section{DAFTAR PUSTAKA}

Advinda, L. 2018. Dasar-dasar Fisiologi Tumbuhan. Penerbit Deepublish (CV BUDI UTAMA). Yogyakarta.

Anhar, A., Doni, F. dan Advinda, L. 2011. Respon Pertumbuhan Tanaman Padi (Oryza sativa L.) Terhadap Introduksi Pseudomonad Fluoresen. Eksakta Vol. 1 Tahun XII Februari 2011.

Bloemberg, G.V. and B.J.J Lugtenberg, 2001. Molecular basis of plant growth promotion and biocontrol by rhizobacteria. Curr. Opinion. Plant. Biol., 4: 343-350. DOI: 10.1016/S1369-5266(00)00183-7

Doktycz, M.J., Pelletier, D.A., Schadt C.W., Tuskan, G.A., Weston, D. 2014. Plant growth promoting rhizobacterium,

Patent US20140206539.

Irwanto. 2003. Pengaruh Hormon IBA (Indole Butyric Acid) Terhadap Keberhasilan Stek Gofasa (Vitex cofassus Reinw). http://www.irwantoshut.com.

Ördög, V and Zoltán, M. 2011. Plant Physiology. Publisher: Debreceni Egyetem, Nyugat-Magyarországi Egyetem, Pannon Egyetem

Pamungkas, T.F., S. Darmanti., B. Raharjo. 2009. Pengaruh konsentrasi dan lama perendaman dalam supernatan Kultur bacillus sp.2 ducc-br-k1.3 terhadap pertumbuhan stek horisontal batang jarak pagar (Jatropha curcas L.) Fisiologi Tumbuhan 3: 131- 140.

Purwanto, E. 2008. Kajian Macam Media Tanam Dan Konsentrasi Iba Terhadap Pertumbuhan Stek Jarak Pagar (Jatropha curcas L.). Tesis. Surakarta: Program Pasca Sarjana, Universitas Sebelas Maret. 
Su, Y.H., Liu, Y.B., and Zhang, X.S. 2011. Auxin-Cytokinin Interaction Regulates Meristem Development. Mol Plant. 2011 Jul; 4(4): 616-625.

van Loon, L. C. 2007. Plant responses to plant growth-promoting rhizobacteria. Eur J Plant Pathol. 2007, 119:243-254.

Wahyudi, A.T., Astuti, R.I., Giyanto. 2011. Screening of Pseudomonas sp. Isolated from Rhizosphere of Soybean Plant as Plant Growth
Promoter and Biocontrol Agent. American Journal of Agricultural and Biological Sciences 6 (1): 134141, 2011.

Wang, Y.H and Irving, H.R. 2011. Developing a Model of Plant Hormone Interactions. Plant Signal Behav. 2011 Apr; 6(4): 494-500.

Wudianto, R. 2002. Membuat Setek, Cangkok dan Okulasi. Jakarta: Penebar Swadaya. 